\title{
ANOMALI RETURN PADA PASAR MODAL INDONESIA (Studi Pada Bank BUMN di Bursa Efek Indonesia)
}

\author{
Iqra Wiarta ${ }^{1}$ \\ ${ }^{1}$ Dosen Universitas Muhammadiyah Jambi \\ Iqra_wiarta2006@yahoo.co.id \\ Dina Daniyanti \\ ${ }^{2}$ Dosen Universitas Islam Negeri STS Jambi \\ Etriya $^{3}$ \\ ${ }^{3}$ Karyawan PT. Bank Pembangunan Daerah Jambi
}

\section{Ringkasan}

Fenomena yang terjadi dipasar modal salah satunya adalah penyimpangan terhadap bentuk pasar modal yang efisien dimana return rata -rata pada bulan januari memiliki kecenderungan yang lebih tinggi jika dibandingkan dengan bulan - bulan lainnya, atau biasanya disebut dengan fenomena januari effect. Penelitian ini berfokus untuk mengindetifikasi fenomena januari effect pada saham-saham bank yang dimiliki oleh negara atau biasanya disebut dengan saham bank Badan Usaha Milik Negara (BUMN) yang terdaftar di Bursa Efek Indonesia (BEI) periode Februari 2010 hingga Januari 2019. Sumber data yang digunakan yaitu data sekunder yang bersumber dari data sekunder yaitu besarnya perubahan harga saham setiap bulan pada saat penutupan di bursa dan metode analisis data menggunakan uji T-test. Hasil penelitian menunjukan bahwa tidak terdapat perbedaan abnormal return saham pada bulan januari dengan bulan lainnya. Sehingga peneliti menyimpulkan tidak terjadi fenomena januari effect pada Bank BUMN dari tahun 2010 sampai dengan 2019 pada 4 bank BUMN yaitu PT. Bank Negara Indonesia Tbk, PT. Bank Rakyat Indonesia Tbk, PT. Bank Tabungan Negara Tbk dan PT. Bank Mandiri Tbk.

Kata Kunci: Abnormal Return, Bank BUMN dan Januari Effect.

\section{PENDAHULUAN}

Dengan kemajuan teknologi dan informasi akan mempermudah masyarakat dalam melakukan investasi baik di sektor riil maupun di sektor keuangan. Fenomena investasi masyarakat pada sektor keuangan terutama pada pasar modal saat ini dapat dilihat dari peningkatan jumlah investor di pasar modal Indonesia yang terus bertambah dari tahun 2010 sampai dengan 2020. Pengertian investasi sendiri menurut Tendelili (2010) yaitu komitmen terhadap sejumlah dana atau sumberdaya lainnya yang dilakukan pada saat ini, dengan tujuan untuk memperoleh sejumlah keuntungan dimasa yang akan datang. Dari pengertian tersebut, dapat disimpulkan pengertian investasi sendiri yaitu menunta untuk menggunakan sumberdaya pada saat ini untuk digunakan pada masa yang akan datang dengan tujuan akan memperoleh keuntungan. 
Peningkatan jumlah investor dipasar modal sendiri akan berdampak terhadap tingkat transkasi di pasar modal yang muara dari transaksi itu sendiri pada industri perbankan. Dengan banyaknya pengguna Industri perbankan, maka industri ini menjadi industri yang paling penting di Indonesia. Terdapat 4 bank yang berbentuk Badan Usaha Milik Negara yang terlisting di Bursa Efek Indonesia dengan capitaliasasi pasar yang besar pula. Keempat bank tersebut yaitu PT. Bank Rakyat Indonesia Tbk, PT. Bank Negara Indonesia Tbk, PT. Bank Tabungan Negara Tbk, dan PT. Bank Mandiri Tbk. Bank BUMN tersebut selain berfungsi sebagai lembaga intermediasi, juga memiliki fungsi sebagai sumber pendapatan bagi negara yaitu berupa deviden kepada pemegang sahamnya, sehingga banyak investor memilih untuk memiliki saham tersebut dikarenakan memiliki kepastian dari deviden yang dibagi setiap tahunnya.

Fenomena yang sering terjadi di pasar modal yaitu anomali pasar. Anomali pasar sendiri terjadi apabila dalam suatu waktu tertentu ada pembentukan dan pengualangan pola atau mengalami perubahan yang dapat diprediksi, sehingga investor dapat membuat pendugaan karena pergerakan harga saham terpola pada saat tertentu, atau dapat dikatakan tidak lagi bergerak secara random atau acak. Salah satu bentuk anomali pasar yaitu januari effect. Menurut Pradyaparamita (2015) januari effect merupakan suatu kondisi anomali yang terjadi di pasar modal dimana pada bulan Januari terjadi kecendrungan rata-rata pengembalian bulanan saham pada bulan ini lebih tinggi dibandingkan dengan bulan-bulan lainnya.

Bertolak dari latar belakang tersebut, maka kami peneliti tertarik untuk meneliti lebih lanjut mengenai anomali pasar yang terjadi di pasar modal Indonesia, pada bulan januari dengan judul penelitian yaitu Anomali Return Pada Pasar Modal Indonesia (Studi Pada Bank BUMN Di Bursa Efek Indonesia)

\section{LANDASAN TEORITIS}

\section{Anomali Pasar}

Menurut Tendelilin (2010) anomali adalah kejadian atau peristiwa menyimpang yang tidak diantisipasi dan yang menawarkan investor peluang untuk memperoleh abnormal return. Cederburga dan O’Doherty (2015) menyatakan di dalam penelitiannya bahwa anomali adalah pola pengembalian saham yang rata-rata tidak konsisten dengan model perilaku harga aset yang berlaku. Sedangkan menurut Trisnadi dan Sedana (2016) anomali pasar (market anomaly) adalah teknik dan strategi yang tampaknya berlawanan dengan konsep teori pasar efisien. Anomali pasar ini selalu dikaitkan dengan konsep atau teori pasar modal yang efisien. Adanya 
anomali (ketidakteraturan) pasar kemudian membentuk salah satu fenomena yang menganggu teori hipotesis pasar modal efisien. Saraswati dkk (2015) menyatakan bahwa pasar tidak dapat benar-benar dikatakan efisien, karena adanya anomali (ketidakteraturan) pasar yang selalu dikaitkan sebagai salah satu bentuk dari fenomena yang menganggu teori hipotesis pasar modal efisien.

\section{Januari Effect}

January effect pertama kali diamati sekitar tahun 1942 oleh seorang banker bernama Sidney B. Wachtel, yang menyatakan bahwa ada kecenderungan performa saham yang tidak aktif meningkat tajam pada bulan Januari. Beberapa teori mengatakan fenomena ini terjadi karena investor retail di Amerika Serikat, yang memiliki saham yang tidak aktif ini, menjual sahamnya dengan alasan pajak pada akhir tahun dan menginvestasikan dananya pada awal tahun. Teori lainnya mengatakan bahwa adanya pembagian bonus di Amerika Serikat yang biasanya dibagikan di Januari, membuat investor banyak membeli saham di Januari sebagai investasi yang membuat harga saham naik.

Penelitian yang dilakukan oleh Yani (2013) menjelaskan bahwa January effect adalah kecenderungan naiknya harga saham antara tanggal 31 Desember sampai dengan akhir minggu pertama pada bulan Januari. Sedangkan pendapat ahli menurut Pratomo (2007) mendefinisikan bahwah January effect merupakan kecenderungan rata-rata return saham pada bulan Januari lebih tinggi dibandingkan bulanbulan lainnya.

\section{Return Saham}

Beberapa ahli mendefinisikan return saham, adapun pendapat ahlinya yaitu menurut Jogiyanto (2013) mendefinisikan return saham merupakan yang diperoleh dari investasi saham. Return dapat berupa return realisasian yang sudah terjadi atau return ekspektasian yang belum terjadi tetapi yang diharapkan akan terjadi dimasa mendatang. Sedangkan menurut Tandelilin (2010) return saham merupakan salah satu faktor yang memotivasi investor berinvestasi dan juga merupakan imbalan atas keberanian investor menanggung resiko atas berinvestasi yang di lakukannya.

Berdasarkan definisi diatas penulis mengambil kesimpulan bahwa return saham merupakan suatu hasil yang di peroleh atau selisih antara jumlah yang diterima dengan jumlah yang diinvestasikan dibagi dengan jumlah yang diinvestasikan dari kegiatan menjual atau membeli suatu saham. 


\section{METODE PENELITIAN}

Penelitian ini merupakan penelitian yang datanya bersumber dari data sekunder yang telah dipublikasi dan diperoleh dari website idx dari bulan februari 2011 sampai dengan bulan januari 2020. Adapun jenis penelitiannya yaitu penelitian kuantitatif yang lebih menekankan pada pengujian teori - teori. Objek penelitian sendiri yaitu bank BUMN yang terdiri dari PT. Bank Rakyat Indonesia Tbk, PT. Bank Negara Indonesia Tbk, PT. Bank Tabungan Negara Tbk, dan PT. Bank Mandiri Tbk. Teknik analisis data yang digunakan dalam penelitian ini yaitu analisis uji beda t-test yang digunakan untuk menguji signifikansi perbedaan abnormal return bulan januari dengan bulan lainnya. Uji beda t-test digunakan untuk menentukan apakah dua sampel yang tidak berhubungan memiliki niali rata - rata yang berbeda.

\section{HASIL DAN PEMBAHASAN}

Peristiwa abnormal return pada bulan januari lebih dikenal dengan istilah januari effect. Untuk dapat melakukan pengujian terhadap abnormal return tersebut maka diperlukan analisis deskriptif. Analisis deskriptif digunakan untuk dapat mengetahui bagaimana gambaran umum mengenai objek penelitian yang akan diteliti. Hasil analisis deskriptif average abnormal return pada bulan lainnya dan abnormal return pada bulan Januari dapat dilihat pada tabel dibawah ini :

Tabel.1 Analisis Deskriptif Descriptive Statistics

\begin{tabular}{|l|r|r|r|r|r|}
\hline & $\mathrm{N}$ & Minimum & \multicolumn{1}{|c|}{ Maximum } & \multicolumn{1}{|c|}{ Mean } & Std. Deviation \\
\hline Januari & 10 &,- 13 &, 11 &, 0170 &, 06897 \\
Selain Januari & 10 &,- 03 &, 10 &, 0234 &, 03700 \\
Valid N (listwise) & 10 & & & \\
\hline
\end{tabular}

Bertolak dari tabel 2 diatas, didapatkan data bahwa hasil analisis deskriptif menunjukan rata-rata retrun abnormal selama periode Februari 2010 sampai dengan periode Januari 2019 terjadi tertinggi pada bulan selain januari dengan rata-rata sebesar 0,234 sedangkan untuk ratarata bulan selain januari sebesar 0,0170. Untuk nilai maksimum dapat dilihat juga bahwa return maksimum terjadi pada bulan januari yaitu sebesar $0,11 \%$ dan untuk return minimum terjadi pada bulan selain januari yaitu sebesar -0,03\%. Jika dilihat hasil perhitungan standar deviasi, maka didapatkan hasil yaitu nilai yang terkecil terdapat pada bulan selain Januari yaitu sebeser 0,037 yang menunjukan bahwa tingkat risiko perdangangan yang rendah jika dibandingkan dengan bulan januari yaitu sebesar 0,06897 yang menunjukan bahwa pada bulan januari tingkat risiko perdangangan bank BUMN lebih tinggi dibandingkan dengan bulan selain januari. 
Selanjutnya untuk dapat mengetahui hubungan antara return bulan januari dan return bulan selain januria maka dilakukan perhitungan terhadap korelasi. Adapun hasil perhitungan korelasinya dapat dilihat pada tabel dibahwa ini :

Tabel 2.

Hasil Perhitungan Paired Samples Correlations

\begin{tabular}{|ll|r|r|r|}
\hline & N & Correlation & Sig. \\
\hline Pair 1 Januari \& Selain Januari & 10 &,- 134 &, 713 \\
\hline
\end{tabular}

Dari tabel diata, didapatkan hasil perhitungan korelasi antara return saham bulan januari dan return saham selain bulan januari. Dengan besaran korelasi yaitu sebesar -0,134 dengan nilai Sig sebesar 0,134. Hasil tersebut menunjukan bahwa 0,713>0,05 berarti tidak terdapat hubungan korelasi antara return bulan januari degan retrun bulan selain bulan januari. Setalah diketahui bahwa tidak terjadi korelasi antara return bulan januari dan return bulan selain januari maka barulah dilakukan pengujiannya. Adapun hasil perhitungan t-test dapat dilihat pada tabel dibawah ini :

Tabel 4

Hasil Perhitungan Paired Samples Test

\begin{tabular}{|c|c|c|c|c|c|c|c|c|}
\hline & \multicolumn{5}{|c|}{ Paired Differences } & \multirow[b]{3}{*}{$\mathrm{t}$} & \multirow[b]{3}{*}{$\mathrm{df}$} & \multirow{3}{*}{$\begin{array}{l}\text { Sig. }(2- \\
\text { tailed) }\end{array}$} \\
\hline & \multirow[b]{2}{*}{ Mean } & \multirow{2}{*}{$\begin{array}{c}\text { Std. } \\
\text { Deviation }\end{array}$} & \multirow{2}{*}{$\begin{array}{l}\text { Std. Error } \\
\text { Mean }\end{array}$} & \multicolumn{2}{|c|}{$\begin{array}{c}95 \% \text { Confidence Interval } \\
\text { of the Difference }\end{array}$} & & & \\
\hline & & & & Lower & Upper & & & \\
\hline $\begin{array}{ll}\text { Pair } & \text { Januari - Selain } \\
1 & \text { Januari }\end{array}$ &,- 00640 &, 08251 & ,02609 &,- 06542 &, 05262 &,- 245 & 9 & ,812 \\
\hline
\end{tabular}

Berdasarkan tabel 4 diatas, didapatkan bahwa pengujian paired samples t-test dengan menggunakan alat spss 23, dapat diketahui bahwa periode Januari 2011 sampai dengan desember 2019 memiliki rata -rata return untuk bank BUMN yang terdapftar di BEI yaitu sebesar -0.00640 dengan standar deviasi yaitu sebesar 0,08251 . Selanjutnya nilai t sebesar 0,245 dengan taraf signifikasinya sebesar 0,812 . Dari data tersebut dapat disimpulkan bahwa nilai signifikan sebesar $0,812>0,05$ maka tidak terdapat perbedaan yang signifikan pada abnormal return saham bank BUMN di BEI selama bulan januari dengan bulan selain januari. Maka dapat dikatakan bahwa saham -saham bank milik negara yang terdaftar di BEI selama periode Februari 2011 sampai dengan Januari 2019 dapat dikatakan efisien. Sehingga dapat disimpulkan bawah tidak terjadi abnormal return pada bulan januari pada bank BUMN yang terlisting di Bursa Efek Indonesia. 


\section{KESIMPULAN}

Bertolok dari hasil dan pembahasan diatas, maka peneliti melakukan kesimpulan terhadap penelitiannya yaitu tidak terjadi abnormal return yaitu pada bulan januari atau yang lebih dikenal dengan istilah januari effect pada Bank BUMN selama periode febuari 2010 sampai dengan januari 2019. Hasil tersebut dapat dilihat dari nilai signifikasi hasil pengujian ttest sebesar 0,812 yang menunjukan bahwa tidak terdapat perbedaan yang signifikan.

\section{DAFTAR PUSTAKA}

Cederburg, S., \& O’Doherty, M. S. (2015). Asset-pricing anomalies at the firm level. Journal of Econometrics, 186(1), 113-128.

Hartono, J. 2005. Pasar Efisien Secara Keputusan. Jakarta: PT. Gramedia Pustaka Utama.

Pratomo, A. W. (2007). January Effect dan Size Effect pada Bursa Efek Jakarta (BEJ) Periode 1998-2005 (Doctoral dissertation, Program Pasca Sarjana Universitas Diponegoro).

Saraswati, A., \& Wirakusuma, M. G. ANALISIS DAY OF THE WEEK EFFECT DAN ROGALSKI EFFECT PADA PERUSAHAAN YANG TERDAFTAR DI LQ45 TAHUN 2015. E-Jurnal Akuntansi, 21(1), 116-143.

Tandellin E. 2010, Analisis Investasi dan Mnajemen Fortofolio Edisi pertama Cetakan pertama. BPFE Yogyakarta.

Trisnadi, M. M., \& Sedana, I. B. P. 2016. Pengujian Anomali Pasar: Day of The Week Effect pada Saham LQ-45 di Bursa Efek Indonesia. E-Jurnal Manajemen, 5(6).

Yani, A,R. 2013. January Effect dan Size Effect pada Perusahaan yang Terdaftar di Bursa Efek www.idx.co.id Indonesia. Universitas Brawijaya Malang. 